\title{
Alě̌ Črnič \\ O KRŠČANSKI EVROPI IN NJENI KULTURI STRAHU PRED ISLAMOM
}

Živimo v časih množičnih strahov pred begunci in migranti. Ker je med njimi večina muslimanov, naj bi to ogrožalo naš način življenja, saj naj bi s svojo menda radikalno drugačno kulturo spodjedali krščanske temelje Evrope. Vse številnejše politične sile se odkrito poslužujejo politik strahu, ki jim zelo očitno ob razmeroma majhnih vložkih prinašajo velike politične dividende; posledično se je širom po Evropi in celotnem zahodnem svetu razrasla kultura strahu pred islamom. ${ }^{1}$ Zdi se, kot da sta strah in iz njega izhajajoče sovraštvo postala najmočnejši gonili politike.

Čeprav ima sodoben begunski val, kot ga $\mathrm{z}$ naravno metaforo pogosto imenujejo množični mediji, zelo jasen nenaravni vir, to je vojaški napad ameriško vodene zahodne koalicije na Irak leta 2003 (glej npr. Šterbenc 2011), ki ga je z Vilensko izjavo neposredno podprla tudi Slovenija, se pričujoče besedilo ne loteva globalnih političnih in geostrateških kontekstov sodobnih zahodnih strahov pred islamom. Namesto te sicer legitimne in $\mathrm{v}$ številnih pogledih nujne ambicije (ki pa smo jo zaradi prostorskih in drugih omejitev prisiljeni pustiti za kako drugo priložnost) analizira zgodovinske vire teh strahov, potem pa razgradi (dekonstruira) na prvi pogled samoumevno enačenje evropske kulture s krščanstvom ter zariše kompleksnejše obrise sodobnih evropskih in za-

1 Glej npr. European Islamophobia Report, dostopno prek https://www.islamophobiaeurope.com. 
hodnih kultur, h katerim so svoje prispevale tudi islamske. ${ }^{2} \mathrm{~S}$ tem upamo na skromen prispevek k boju za »evropsko kulturo« in "naš način življenja«, ki ga preprosto ne moremo učinkovito zastaviti, dokler zares ne razumemo, kaj ju sploh konstituira in kaj ogroža.

\section{Islam kot strašljiva fantazma Zahoda}

Evropa se vse od svojih začetkov ni konstituirala le na temelju skupnih elementov, temveč vsaj v enaki meri tudi v nasprotju z Drugim. Pri ustvarjanju identitete na način per negationem, torej primarno $\mathrm{z}$ določanjem, kdo in kaj nismo, je kot kontrapod služil predvsem islam. Korenine sodobnih protiislamskih sentimentov tako segajo skoraj tisočletje v zgodovino, vse do križarskih vojn, na Slovenskem pa se vse do danes napajajo predvsem s spomini na turške vpade.

Islam se je od samega nastanka $v$ prvi polovici sedmega stoletja bliskovito širil tudi z nasiljem. A redukcija njegove osupljive uspešnosti na vojaški element spregleduje številne druge dejavnike privlačnosti nove in izjemno vitalne religije, ki je nadvse učinkovito pritegnila ljudske množice širom ozemelj, ki jih je dosegla. Sprva in še dolgo razmeroma maloštevilna skupnost muslimanov izključno prek vojaškega instrumenta preprosto ne bi zmogla tako bliskovitega širjenja in, kar je še pomembnejše, poznejšega vzdrževanja kontrole nad pridobljenimi ozemlji in tamkajšnjimi družbami.

Prvi kristjani, ki so prišli v stik z muslimani, so bili t. i. vzhodni kristjani, na Zahod pa so informacije o islamu prvi prinesli romarji $\mathrm{v}$ »Sveto deželo«. Njihova pričevanja niso bila posebej strašljiva, poročali so o bolj ali manj plodnem ali vsaj znosnem sobivanju »ljudi knjige«, tj. pripadnikov treh velikih abrahamskih monoteističnih religij, ki so svoje verske obrede neredko opravljali celo v istih prostorih.

Konfliktnejši odnos med zahodnimi kristjani in muslimani prinese začetek osmega stoletja, ko začne (na povabilo enega od krščanskih vla-

2 Dotične problematike smo že obdelali tudi v prispevku za zbornik Islamske skupnosti $v$ RS, ki je $\mathrm{v}$ času oddaje tega besedila v pripravi za tisk. 
darjev v spopadu za prevlado nad drugimi!) Tarik ibn Zijard iz severne Afrike uspešen osvajalni pohod na Iberski polotok, kmalu pa občasno čez Pireneje vdira tudi na frankovska ozemlja. A v zahodni zaznavi tistega časa so Mavri oz. Saraceni, kot so jih imenovali, pač še eni neverniki, ki sicer ogrožajo krščanski svet, vendar nič bolj kot drugi pogani in barbari (med njimi tudi Slovani). Različni zahodni krščanski monarhi so v boju za prevlado nad vrstniki brez zadržkov sklepali zavezništva $\mathrm{z}$ muslimani, ki tudi sami niso bili vedno enotni.

Zametke eksplicitno sovražnega odnosa do muslimanov in islama kot glavnega nasprotnika, poosebljenja zla, zasledimo šele v drugi polovici 9. stoletja. Takrat papež Janez VIII. začne z doktrinarno vzpostavitvijo kristjanov kot skupnosti, kot enotnega družbenega in mističnega telesa, hkrati pa demonizira muslimane in ves krščanski svet pozove $\mathrm{k}$ vojni proti njim. To je začetek kompleksnih procesov homogeniziranja krščanstva in njegovega vzpostavljanja kot enotne družbene skupnosti (s transcendentalnimi utemeljitvami), ki v svojem jedru nosi antagonizem do muslimanov, kot nam to poglobljeno pokaže Tomaž Mastnak (1996) v svoji eruditski knjigi o »kristjanstvu« in muslimanih.

A ti procesi so zahtevali svoj čas - dobri dve stoletji sta bili potrebni, da so se muslimani v zahodni zavesti iz ene mnogih in raznolikih skupin nevernikov spremenili v glavnega sovražnika krščanskega sveta, njihova religija pa je postala demonska in eksplicitno povezana $\mathrm{z}$ Antikristom. Na samem koncu enajstega stoletja ti procesi kulminirajo v prvi križarski vojni - vojni, ki je prvič v zgodovini neposredno povezana (tudi) $\mathrm{z}$ religijskimi motivi in predvsem s transcendentalnimi utemeljitvami ${ }^{3}$ (glej Mastnak 2017).

Pri tem velja poudariti dvoje. Zahodni kristjani o muslimanih v tistem času niso vedeli tako rekoč ničesar, samostanski učenjaki niso pre-

3 Res je Bog krščanskim vojščakom v njihovih prizadevanjih pomagal že prej, a v križarskih vojnah nenadoma začne kar neposredno delovati skozi njih. In ne le da vojno nasilje ne velja več za greh, temveč postane vrlina, s katero si je mogoče prislužiti odpis grehov. Zato papež Urban II. leta $1095 \mathrm{ni}$ imel omembe vrednih težav z novačenjem preprostih krščanskih množic za prvega od križarskih bojnih pohodov, ki so se od siceršnjih roparskih vpadov veliko bolj kot po načinu delovanja ali po izplenu ločili po bojnem klicu, ki jih je vodil: Deus Vult, Bog tako hoče! 
učevali niti njihove religije niti kulture, prevladujoča večina križarjev pa ni nikoli prej srečala nobenega muslimana, saj je prihajala iz dežel, ki so bile daleč od islamskih. In drugič: »Muslimani za te vojne niso dali nobenega povoda. Zahodnih kristjanov niso ogrožali [...] Zahodnjaki so reševali svoje probleme na tuj račun. Pri tem so ustvarili globoko sovraštvo med krščanskim in muslimanskim svetom, sovraštvo, ki je strukturno, ker je vgrajeno v zgradbo našega sveta.« (Mastnak 2017, 78)

Tako so bili v razmerah, ki so kulminirale v križarskih vojnah, izpolnjeni pogoji za rojstvo ideje Evrope kot politične skupnosti, ki v svojem bistvu temelji na antagonizmu ali že kar eksplicitnem sovraštvu do muslimanov. Ti procesi tudi de facto zadnjo stopnjo dosežejo sredi petnajstega stoletja, ko Osmani pod vodstvom Mehmeda Osvajalca leta 1453 zavzamejo bizantinsko prestolnico in središče vzhodnega krščanstva, Konstantinopel. To poenoti prej stoletja radikalno razcepljen krščanski svet na latinski in vzhodni, pravoslavni del, na mestu antagonističnega Drugega pa v zahodni imaginaciji Mavra/Saracena zamenja Turek. Začnejo se mobilizacije proti turškemu ogrožanju Evrope, ki v zavesti njenih heterogenih ljudstev prvič postane prostor skupne identitete.

Spomini na turške vpade, pred katerimi so se naši predniki opozarjali s kresovi, da bi se lahko še pravočasno umaknili v obzidana cerkvena zavetja - tabore, vse do danes ostajajo živi tudi v slovenski kulturi. Ne le v ljudskih pesmih o devicah, ugrabljenih za hareme, temveč tudi $v$ osnovnošolskih učbenikih, $v$ katerih se še male glavice seznanijo z Župančičevim Turkom (s fesom, krivo sabljo in bradavico na nosu) in Levstikovim Martinom Krpanom (ki pred zlobnim Brdavsom reši cesarski Dunaj), le malo večje pa $\mathrm{z}$ Jurčičevim slovenskim janičarjem Jurijem Kozjakom in Sketovo povestjo iz turških časov, Miklovo Zalo. Kurikularno seznanjanje s tem nedvomno burnim obdobjem slovenske zgodovine samo po sebi seveda ne bi bilo problematično, če ne bi vodsotnosti dodatnih kontekstualnih refleksij predvsem nekritično obnavljalo starih stereotipov o barbarsko brezbožnem, neusmiljeno krutem Turku, ki brezvestno ogroža krščanski svet. ${ }^{4}$

4 Viri teh stereotipov so predvsem dvojni: po eni strani imajo korenine v pamfletih iz šestnajstega stoletja, v katerih Habsburgi s (pretiranim) poudarjanjem turške 
Ti stereotipi, ki nastanejo in se ohranjajo skozi (neozaveščene) kompleksne kulturne procese konstrukcije drugosti, kar v družboslovju imenujemo drugačenje (glej Muršič 2012), večplastno identiteto »Turka« sploščajo na manihejsko črno-belo podobo, v kateri nas, ki smo seveda na strani dobrega, ogroža to poosebljenje zla. Predvsem pa njegovo kompleksno identiteto reducirajo na religijo, kot je to slikovito opisal Aleš Debeljak (2009, 55): „Etnična oznaka ,Turek' v slovenskih kolektivnih predstavah ni nič drugega kot metaforični povzetek predsodkov do tiste vere, pred katero se je v strahu stiskalo srce vsej srednjeveški Evropi: islam!«

Tovrstni procesi drugačenja seveda niso slovenska posebnost, zasledimo jih lahko na vseh mejnih območjih, kjer se stikata in soočata Vzhod in Zahod. Praviloma temeljijo na obmejni variaciji orientalizma, ki se od (post)kolonialnih drugačenj »Orienta «, kot jih v svojem klasičnem delu definira Edward Said (1996), razlikujejo predvsem po neposrednem in najpogosteje konfliktnem soočanju z Drugim, tj. »Turkom« oz. muslimanom 5 (Gingrich 1998). Predvsem pa naš, slovenski primer teh procesov drugačenja temelji na srednjeveškem mitu o antemurale christianitatis, predzidju oz. braniku krščanskega sveta, ki je v našem delu Evrope deloma preživel vse do danes (glej npr. Bartulović 2012). Številne

grožnje krepijo svojo legitimnost in moč tako znotraj lastnega cesarstva kot proti svojim sovražnikom Francozom in protestantom (Jezernik 2012, 19-20), po drugi strani pa so plod sočasnih zavestnih prizadevanj samega osmanskega sultana in njegovega dvora, ki sta svojo osvajalsko taktiko načrtno gradila na (prav tako pretiranem) poudarjanju a) nasilja, b) arogance $z$ ukazovalno, pompozno, oholo, žaljivo in izzivalno retoriko ter c) blišča v diplomatski, vojaški in družbeni sferi, $\mathrm{s}$ čimer sta pogosto učinkovito izvajala psihološke pritiske na svoje nasprotnike in sovražnike (Kumrular 2012).

5 Medtem ko klasični (tj. Saidov) orientalizem črpa predvsem iz elitne kulture, sestavljajo obmejni orientalizem tudi ljudski miti, ki metaforično obeležujejo ključna srečanja krščanskega sveta z muslimanskim. Če je subjekt klasičnega orientalizma oddaljen, primitiven in inferioren, lahko moškega kot ženskega spola, pri čemer je slednji lahko povezan tudi z erotično fascinacijo, je obmejni orientalec vedno moškega spola (ženska v tej različici orientalizma nastopa zgolj v vlogi nemočne žrtve, ki jo je treba ubraniti pred muslimani) in primarno vojak ter neposreden tekmec (Gingrich 1998). 
dokaze tega smo lahko spremljali v vojnah ob razpadu Jugoslavije, ko so se predvsem srbski nacionalisti pred zahodno javnostjo dolgo uspešno predstavljali kot zadnji branik krščanstva pred menda ogrožajočim bosanskim islamom, na vojnih frontah pa so Bošnjake pogosto etiketirali z imenom »Turki «. O tem nadvse zgovorno pričajo tudi nekatere žolčne domače javne polemike glede gradnje džamije v Ljubljani na začetku našega stoletja (glej Dragoš 2003, 2004 in 2014). Nazadnje pa lahko presenetljivo vitalne elemente tega srednjeveškega mita spremljamo vse do danes, ko od politikov, škofov, različnih javnih osebnosti in tudi od preprostih ljudi poslušamo in beremo eksplicitne primerjave množic beguncev in migrantov s turškimi vpadi ter špekulacije o zarotniški načrtni organizaciji zadnje begunske krize, ki naj bi bila zavestno naperjena proti jedru krščanske Evrope.

Tako na prvi pogled trdovratna vztrajnost srednjeveškega mita o antemurale christianitatis potrjuje Mastnakovo tezo, da je »sovraštvo [zahodnih kristjanov do muslimanskega sveta] $\mathrm{v}$ jedru evropske identitete in bo z nami, dokler bo obstajala Evropa in dokler se bomo sklicevali na evropske vrednote«. (Mastnak 2017, 74) A prehitra privolitev v to smelo tezo bi bila vendarle prezgodnja vdaja - teza namreč velja le, dokler evropske vrednote enačimo izključno s krščanstvom, kar je nedvomno veljalo za srednji vek, od razsvetljenskega preloma naprej pa evropska identiteta postane veliko manj enoznačna.

\section{Eksluzivno krščanska in/ali pluralistično sekularna Evropa}

Povezava evropske kulture in identitete s krščanstvom je seveda očitna in tako rekoč samoumevna. O njej ne pričajo le zgodovinski začetki Evrope kot eksplicitno krščanske skupnosti, temveč tudi izjemna zgodovinska vloga samostanskih centrov vednosti in omike, ključni vpliv predvsem Jezuitov na razvoj šolstva, protestantski vplivi na razvoj nacionalnih jezikov in nacionalnih identitet itd. Potrjujejo jo tudi sodobne razmere, v katerih večina Evropejcev še vedno izreka vsaj nominalno 
pripadnost krščanstvu, bodisi katolicizmu bodisi kateri od protestantskih denominacij.

In še več: sodobnih zahodnih sekulariziranih družb ne moremo razumeti brez $\mathrm{v}$ marsičem usodnega vpliva krščanskih idej in konceptov na njihov nastanek in razvoj (glej npr. Stark 2005). Z rojstvom Božjega sina linearno dojemanje časa izpodrine cikličnega, šele po tem se lahko razvije moderna ideja o napredku zgodovine. Krščanstvo prek teološke ideje, da je človek ustvarjen po božji podobi in zato nekaj dobrega, iz človeka (v božjih očeh) naredi osebo. To ima, skupaj z dogmo o Kristusovem žrtvovanju za človeka in možnostjo človekove individualne odrešitve, izjemen vpliv na razvoj številnih temeljnih konceptov, na katerih smo zgradili naš moderni svet: enakost, demokracija, toleranca, solidarnost, človekovo dostojanstvo, pravice, individualizem itd. Vloga človekovega razuma v (zahodni) krščanski teologiji je bila izjemno pomembna za nastanek racionalizma in razvoj moderne znanosti. Krščanstvo je odločilno pripomoglo k nastanku kapitalizma (brez katerega si, kljub več kot upravičenim kritikam, sodobnega sveta preprosto ni mogoče predstavljati), kot je v znameniti knjigi Protestantska etika in duh kapitalizma prepričljivo pokazal sociološki klasik Max Weber ([1905] 1988). Iz krvavih medkrščanskih spopadov, ki jih po koncu tridesetletne vojne leta 1648 (skoraj celo stoletje po augsburškem miru, ki prizna luteranstvo) zaključi westfalski mir z uveljavitvijo načela cuius regio, eius religio (čigar ozemlje, tistega religija), se rodi mednarodno pravo, ki temelji na subjektiviteti državnih tvorb in na suvereni pravici, da nobena ne posega v notranje zadeve drugih. Celo sodobna sekularna politična ureditev, ki temelji na ločitvi vrednostnih sfer, predvsem politične in religijske, ima jasne korenine v biblijskem »daj cesarju, kar je cesarjevega, in Bogu, kar je božjega«.

A ob tem je nujno poudariti, da so se omenjeni koncepti kljub svojim izvorom (tudi) v krščanstvu razvijali postopoma, da jih med njihovim razvojem, na katerega so vplivale tudi številne druge tradicije, niti približno niso razumeli enoznačno (ideja o človekovem dostojanstvu je bila npr. zelo dolgo omejena zgolj na pripadnike simbolnega, tj. krščanskega občestva, zato še v zgodnji moderni dobi zasledimo debate o tem, ali 
nekristjani - npr. Indijanci v Novem svetu - sploh imajo dušo) in da so ti danes zelo drugačni od svojih virov pred stoletji in tisočletji. ${ }^{6}$ Številni sodobni koncepti s krščanskimi idejnimi koreninami se razvijejo ob in kljub eksplicitnemu ter pogosto nadvse aktivnemu nasprotovanju cerkve. Niso plod samoumevne evolucije, temveč so mukoma izborjeni in svojo sodobno obliko v smeri demokracije, svobode govora, človekovih pravic, enakopravnosti ipd. dobijo šele v razsvetljenski in postrazsvetljenski dobi.

Prav tako velja spomniti, da del sveta, ki ga danes razumemo pod pojmom Evropa, ni že kar "po naravi« in od zmeraj krščanski. Poreklo največje svetovne religije ni evropsko, kot bi se nemara zdelo zdravi kmečki pameti, temveč - enako kot obeh abrahamskih sorodnic, judaizma in islama - bližnjevzhodno. Kristjanizacijo Evrope tvorijo kompleksni, neredko nasilni in več kot tisočletje dolgi procesi (običajno se je najprej spreobračalo plemstvo in potem zelo počasi skozi več generacij še preprosto ljudstvo): od leta 381 , ko krščanstvo postane uradna religija Rimskega imperija, do dokončnega pokristjanjenja Litvancev v začetku petnajstega stoletja in čisto nazadnje še rekonkviste Španije in Portugalske leta 1492 - istega leta, ko Kolumb »odkrije« Ameriko in človeštvo vstopi v novo, moderno ero.?

6 Goreči zagovorniki ekskluzivno krščanske narave Zahoda bi morali upoštevati, da bi se cerkveni očetje ob današnjih »zahodnih vrednotah«, ki naj bi bile predvsem krščanske, bržkone zgrozili.

7 Najprej v četrtem stoletju Konstantin z Milanskim ediktom zaukaže strpnost do kristjanov, leta 381 krščanstvo postane uradna religija Rimskega imperija (Teodozij pa prepove t. i. "poganske« religijske obrede). Potem v petem stoletju počasi spreobračajo nekatera germanska plemena (npr. Gote). Ob samem izteku petega stoletja se spreobrne frankovski kralj Clovis oz. Clodovic I., frankovsko ljudstvo pa krščanstvo sprejema vse do konca sedmega stoletja. Konec šestega stoletja se mu v veri postopno pridružijo Anglosaksonci na Britanskem otočju, Sv. Patrik pokristjani keltsko Irsko in del Škotske. Slovansko Veliko Moravijo pokristjanijo Franki in Bizantinski misijonarji iz južne Italije in Dalmacije v začetku devetega stoletja, kmalu zatem bizantinska misijonarja Ciril in Metod uvedeta prvo slovansko pisavo (glagolico), v staroslovanščino prevedeta Biblijo in v Srbiji in Bolgariji uvedeta krščanstvo kot državno religijo. Alpske Slovane v Karantaniji začnejo pokristjanjevati že sredi osmega stoletja (knez Hotimir v Prešernovem Krstu pri Savici), s prvimi kristjani iz Ogleja pa se srečajo že dobro stoletje prej. Leta 966 se krsti prvi 
Takrat se začne prva, imperialistična globalizacija, Zahod pa kmalu pretrese reformacija. Luther božjo avtoriteto iztrga iz prej izključno rimske posesti, protestantizem prinese individualizacijo božjega razodetja in s tem nakaže poznejši obrat od Boga k človeku. To pomeni konec srednjeveškega enovitega latinskega sveta. Gutenbergov revolucionarni izum tiska omogoči lažjo dostopnost prevodov Biblije $v$ ljudske jezike, hkrati pa širjenje najrazličnejših idej in v rastoči množici novih knjig (med katerimi večina kmalu ni več v latinščini) osrednje mesto namesto Boga postopoma zavzema človek. Tako se $\mathrm{z}$ nastopom modernosti v Evropi religijski kriterij počasi umakne etničnemu, ob tem pa se korakoma razvije moderna toleranca, ki ne izhaja več iz skupnosti, temveč iz posameznika. Rodita se renesansa in humanizem. Transcendentalno utemeljen sistem racionalnosti, ki resnico določa glede na religijsko dogmo, postopoma nadomešča nov tip racionalnosti, ki izhaja iz opazovanja, empiricizma in razumske presoje, kar pripelje do znanstvene revolucije in razsvetljenskega preloma. Šele ta konec enovite, dogmatske krščanske Evrope pripelje do svetovne prevlade Zahoda, ki temelji predvsem na modernem konceptu ločitve vrednostnih sfer, ko se različna področja družbenega in zasebnega življenja izvijejo izpod prejšnjega jeklenega prijema cerkve (glej Debeljak 2009b). Začne se sekularizacija, ena ključnih determinant modernega sveta.

Tako ob razmisleku o krščanski Evropi ne moremo spregledati tudi drugih virov, brez katerih je danes ne bi bilo, predvsem predhodnih antičnih in poznejših renesančnih ter humanističnih in številnih drugih. Ideja o Evropi kot čisti krščanski civilizaciji je fikcija, nobena civilizacija ne obstaja sama zase, ločeno od drugih. Civilizacije se vedno stikajo, komunicirajo, včasih tudi konfliktno; predvsem pa se medsebojno op-

vladar združenega poljskega kraljestva Mieszko I., a traja še približno tri stoletja, da katolicizem postane večinska religija na Poljskem. Severna germanska plemena sprejmejo krščanstvo šele $\mathrm{v}$ dvanajstem stoletju, izjemno počasno je pokristjanjevanje Skandinavije, ki se sicer začne že v osmem stoletju, konča pa šele do dvanajstega, pri čemer starodavna nordijska verovanja vzporedno živijo naprej. Po tem katoliški kralji Danske in Švedske v t. i. nordijskih oz. baltskih križarskih vojnah pokristjanijo še Balte, dokončno šele do začetka petnajstega stoletja. 
lajajo - in si šele s tem zagotavljajo svojo vitalnost in dolgoročno preživetje (Debeljak 2009b).

Zato ne more biti posebno presenečenje, da se pred poldrugim desetletjem burne polemike okoli vpisa krščanske dediščine v preambulo ustave EU niso iztekle $\mathrm{v}$ skladu $\mathrm{z}$ intenzivnimi prizadevanji papeža Janeza Pavla II., ki je junija 2003 izdal dokument Ecclesia in Europa in $\mathrm{v}$ njem eksplicitno pozval $\mathrm{k}$ omembi krščanske dediščine, saj naj bi ta ključno »oblikovala kulturo celine«, niti se niso izšle v skladu z željami evropskih Judov in muslimanov po omembi Boga (glej Milton 2010). Prvo bi namreč iz simbolnih temeljev Evrope izključilo drugi dve abrahamski religiji, drugo pa bi (vsaj implicitno) zanikalo evropske razsvetljenske pridobitve. Zato se je $\mathrm{v}$ končni različici preambule ustave znašlo kompromisno besedilo, ki le na splošno omenja »kulturno, religijsko in humanistično dediščino Evrope« in v njej »središčno vlogo človeške osebe in njenih neodtujljivih pravic«. ${ }^{8}$

Sodobno evropsko kulturo torej nedvomno določa krščanstvo, a tudi predhodna grško-rimska antika ter poznejši renesansa in humanizem ter razsvetljenstvo. Zaradi svojstvene zmesi vseh teh virov danes jedro evropskih in zahodnih vrednot tvori predvsem pluralizem, ki ga zagotavlja enakopravnost različnih religijskih in nereligijskih svetovnih nazorov. Evropska sekularnost, ki se napaja tudi iz krščanske tradicije, pa je nujni pogoj za sodobni koncept religijske svobode, ki poleg dominantne evropske in svetovne religije (v njenih različnih izraznih oblikah) vključuje tudi nekrščanske, alternativne in »neavtohtone« religije. A med zadnje bi le težko šteli islam, ki je skozi stoletja pomembno prispeval k oblikovanju evropske kulture.

\section{Islamski prispevki k evropski kulturi}

Ob očitnem dejstvu, da islam od srednjega veka pa vse do danes velja za tistega radikalnega Drugega, v luči katerega šele lahko definira-

8 Ustavo EU so potem maja 2005 na referendumih zavrnili Francozi in Nizozemci, splošna omemba religije pa se je $\mathrm{v}$ isti obliki znašla v preambuli decembra 2007 sprejetega Lizbonskega sporazuma. 
mo, kdo zahodnjaki smo, že le malo globlji pogled razkrije, da ta religija vendarle ni tako radikalno drugačna od judovsko-krščanske tradicije, $s$ katero ponavadi povezujemo svojo identiteto. Nasprotno, s to tradicijo je neločljivo povezana, saj iz nje izhaja. Islam je namreč (gledano kronološko) tretja od abrahamskih monoteističnih religij, ki si - kljub evidentno različnim teološkim razumevanjem - delijo istega Boga in skupne preroke. ${ }^{9}$ Judovstvo, krščanstvo in islam si delijo duhovne korenine, stoletni spori med njimi pa bolj kot iz medsebojnih razlik izhajajo iz njihovih sorodnosti, ki številna ostra nesoglasja šele omogočajo.

Ko so npr. krščanski menihi iz znamenite opatije Cluny v dvanajstem stoletju prevedli Koran, jim - v nasprotju s prevajalci v turščino, farsi in urdujščino - ni bilo težko najti latinskih sopomenk številnim ključnim arabskim konceptom. To zgovorno priča o številnih duhovnih in kulturnih sorodnostih predvsem med univerzalističnima ( $\mathrm{v}$ nasprotju $\mathrm{z}$ rodovno izključujočim judaizmom) krščanstvom in islamom (glej Debeljak 2009a, 57-59).

Kristjani in muslimani zelo dobro vejo, na kaj merijo, ko drug drugega trdovratno obkladajo z zmerljivko »nevernik«, tj. nekdo, ki bi pravo resnico moral spoznati, pa jo bodisi zavestno zavrača bodisi životari $\mathrm{v}$ slepi nevednosti. Poskusite $\mathrm{z}$ »nevernikom « pošteno užaliti koga v budističnem, konfucijskem ali hinduističnem svetu, pa boste videli, kako vas bojo začudeno gledali. Za razumevanje ene resnice, enega kriterija, ene dogme preprosto nimajo predstavnih in pojmovnih orodij. $\mathrm{Z}$ drugimi besedami: prav zato, ker imata islam in krščanstvo skupne duhovne temelje, sploh šele lahko tekmujeta za prvenstvo v kontroli nad duša$\mathrm{mi}$, ozemljem in bogastvom. (Debeljak 2009a, 58)

Izvorov starih antagonizmov med evropsko in islamsko kulturo tako ne kaže iskati toliko v njunih domnevno nepremostljivih razlikah kot $\mathrm{v}$ njunih sorodnostih: muslimanov se na Zahodu ne bojimo zato, ker so tako radikalno drugačni od nas, temveč, ker so nam presenetljivo podobni. Podobni pa si nismo le zaradi skupnih virov glavnih religijskih tradicij, temveč tudi zaradi številnih neposrednih muslimanskih prispevkov k evropski kulturi.

9 Ibrahim, Musa in Isa so arabska imena za Abrahama, Mojzesa in Jezusa. 
Ko leta 711 berberski muslimani s Pirinejskega polotoka (res da nasilno) izženejo šele pred kratkim pokristjanjene Vizigote, se tam kmalu razvije cvetoča civilizacija Al-Andaluz. Konglomerat muslimanskih kraljevin pod močno vojaško zaščito in nadvse učinkovito administracijo omogoči razcvet kulture in znanosti, ki jima na ozemljih, ki jih pozneje začnemo imenovati s skupnim imenom Evropa, ni bilo para. Andaluzija je eno od središč, v katerih se razcveti t. i. »zlata islamska doba«, ki se začne konec osmega stoletja, ko abasidski kalif Harun AlRašid v Bagdadu ustanovi Hišo modrosti, kjer sistematično zbirajo knjige iz vsega sveta, študirajo, prevajajo in poučujejo. Poleg perzijskih in starodavnih indijskih virov jih zanima predvsem antična grška misel. Tako npr. krščanski svet, ki se v prvih stoletjih - motiviran skoraj izključno s spoznanjem Boga in s posmrtno eksistenco - opre predvsem na Platona, šele v trinajstem stoletju odkrije bolj empiricističnega in $\mathrm{v}$ srednjem veku pozabljenega Aristotela, in sicer prek arabskih prevodov in njihovih izčrpnih komentarjev.

A ta bogata racionalistična tradicija $v$ islamski misli, ki jo je nekoč nadvse zgovorno ilustriral znameniti rek Ex oriente lux (z Vzhoda prihaja luč), je v današnji zahodni manihejski percepciji tako rekoč popolnoma spregledana, za njena velika imena je zunaj intelektualnih subkultur slišal komaj kdo. ${ }^{10}$ Islamska »zlata doba« je med osmim in trinajstim

10 Ali al-Hasan Ibn al-Haitham (965, Basra - 1040, Kairo), v latinskem svetu poznan kot Alhazen, je bil pionir optike, stoletja pred zahodno renesanso je s postavljanjem hipotez in njihovim sistematičnim preverjanjem $\mathrm{z}$ eksperimenti in matematičnimi modeli utemeljil znanstveno metodo. Perzijec Ibn Sina (980-1037) oz. Avicenna, ki je večji del življenja deloval v Isfahanu, je - skupaj s Hipokratom in Galenom, na katera se eksplicitno opira - utemeljitelj klasične medicinske vede. Njegovo celovito enciklopedijo medicinskega znanja starega veka (poleg arabskega tudi grškega, rimskega, perzijskega in indijskega) z naslovom Canon Medicinae so še stoletja po njegovem nastanku kot učbenik uporabljali tudi na Zahodu. Najbolj poznan je bržkone Ibn Rušd (1126, Cordoba - 1198, Marakeš) ali Averroes, največji muslimanski komentator Aristotela, ki je imel velikanski vpliv na krščanske mislece, tudi na Tomaža Akvinskega (kot vemo, se sholastika v veliki meri opre na Aristotelovo logiko). Ali pa komaj kaj manj pomemben, čeprav na Zahodu domala neznan Ibn Khaldun (1332-1406), andaluzijski zgodovinar, protosociolog in protodemograf, ki je razvil osnovni koncept družbene kohezije in ekstenziv- 
(po nekaterih interpretacijah pa celo petnajstim) stoletjem v marsičem postavila temelje evropski renesansi in moderni znanstveni revoluciji. "Ne ena ne druga se res nista zgodili v islamskem svetu, a brez njega se prav mogoče ne bi zgodili niti v Evropi, vsaj ne na tak način, kot sta se.» (Malik 2014) Mi pa namesto priznanja in zavestnega črpanja iz te izjemne dediščine poleg skoraj osmih stoletij (!) cvetoče islamske civilizacije na Iberskem polotoku (711-1492) sistematično pozabljamo tudi več kot šest stoletij (!) kontinuirane zgodovine muslimanov v Bosni. In v Litvi, kjer je veliki vojvoda Vytautas oz. Witold leta 1397 - v času, ko Litvance šele pokristjanjujejo - muslimanom eksplicitno podelil posebne pravice, kar jim je omogočilo obstoj vse do današnjih dni.

Evropski muslimani torej povsem očitno niso zgolj sodobni begunci z razrušenega Bližnjega vzhoda niti ne gre samo za drugo ali tretjo generacijo priseljencev iz nekdanjih evropskih kolonij, temveč v Evropi beležimo dolga stoletja njihove kontinuirane, kreativne in plodne prisotnosti. A kljub temu jih v naši kulturi še vedno razumemo kot radikalne tujke.

\section{Zaključek: sekularnost kot vzvod novoveške zahodne prevlade in garant sodobne religijske svobode}

Ob navedenih zgodovinskih dejstvih ne bi smelo biti pretežko razumeti Mustafe Cerića, nekdanjega velikega muftija Bosne in Hercegovine, ki neutrudno ponavlja, da islam ni imigrantska religija, in to utemeljuje s primerom bošnjaškega avtohtonega evropskega islama. Prav tako v tej luči povsem legitimno zveni predlog Silvia Ferrarija (2003), da bi $\mathrm{v}$ temeljne evropske listine namesto prej omenjene splošne formulacije eksplicitno zapisali »dediščino, ki je sestavljena iz grške in rimske civilizacije, judovske in krščanske religijske tradicije $\mathrm{v}$ plodnem dialogu $\mathrm{z}$ islamsko tradicijo, in filozofskih tokov razsvetljenske dobe«. A v pra-

no ter poglobljeno pisal o družbenih konfliktih, cikličnem razvoju civilizacij, politični ekonomiji, teoriji denarja in - celih pet stoletij pred Darwinom - celo o evoluciji. 
ksi to očitno ni izvedljivo, tudi zaradi antagonizmov med sodobnim krščanstvom in a) islamom ter b) sekularizmom.

Procese drugačenja islama in muslimanov, ki zakrivajo sorodnosti z zahodno kulturo in ustvarjajo fantazmo radikalne drugosti, smo analizirali na prejšnjih straneh. Prav tako smo prikazali pomembne islamske vplive na razvoj sodobne zahodne kulture, ki je brez dvoma tudi, ne pa ekskluzivno krščanska. Pri čemer velja iti še korak dlje in eksplicitno poudariti pluralnost ne le evropskih zahodnih kultur, temveč tudi islamskih, zaradi česar je poenostavljeno zoperstavljanje islama in Zahoda že na analitični ravni nadvse problematično. Tudi za islamsko zgodovino sta, tako kot za vsako drugo, značilni pestrost in kompleksnost - islamski svet je bil vselej heterogen, kar kljub njegovi nedavni homogenizaciji zaradi problematičnih političnih, ekonomskih in še posebej vojaških posegov Zahoda velja tudi danes. Celo pahljačo raznolikih razumevanj Boga, človeka, družbe, kulture in politike najdemo tako v muslimanskih državah Bližnjega vzhoda, Azije in Afrike kot tudi med evropskimi muslimani. $V$ zadnjih desetletjih se očitno razvijajo »različni evropski islami, tako individualni kot skupinski, ko se muslimani različnih etničnih in razrednih porekel $\mathrm{z}$ različnimi hitrostmi integrirajo $\mathrm{v}$ evropske nacije." (Moe 2017)

Zato so sodobna srečevanja islamov in Zahodov veliko kompleksnejša od reduciranih manihejskih percepcij trkov med zaostalo, barbarsko, radikalno patriarhalno in inherentno nasilno religiozno tradicijo na eni strani z razsvetljensko, pluralno, svobodoljubno in demokratično kulturo na drugi. Da je resničnost neprimerno kompleksnejša od te sploščene, pogosto demagoške podobe, nemara najzgovorneje dokazuje primer Sadiqa Khana, ki je bil maja $2016 \mathrm{z}$ izrazito levičarskim programom in kljub eksplicitno liberalnim stališčem do istospolnih oseb prepričljivo izvoljen za londonskega župana tudi s prevladujočo večino glasov menda "po naravi« izrazito konservativnih muslimanov (Shterin 2017). Hkrati pa lahko na drugi strani vidimo, da so številni zahodni tradicionalisti $\mathrm{s}$ svojim enoznačno konservativnim odnosom do sveta $\mathrm{v}$ številnih točkah srhljivo podobni islamistom. 
Drugo pomembno vprašanje se nanaša na evropsko sekularnost, ki naj bi bila religiji sovražna, zaradi domnevne vrednotne praznine in relativizma pa naj bi prav tako ogrožala evropsko krščansko identiteto. Eksplicitno zavračanje povezave političnega sistema $\mathrm{z}$ religijo (oz. s katerim koli svetovnim nazorom) prinese razsvetljenski prelom, po katerem je religija sicer še lahko inspiracija za politične izbire (kot je to izraženo npr. v dolgi evropski krščansko-demokratski tradiciji), ne more pa biti njihova edina utemeljitev: tako npr. zagovarjanje prepovedi splava in/ali istospolnih porok $\mathrm{z}$ argumentom nasprotovanja božjim zakonom ni več dovolj, moderna politična legitimnost zahteva univerzalnejše racionalne argumente. Da razsvetljenska ločitev vrednostnih sfer ni vedno pogodu krščanskim cerkvam, ni tako težko razumeti, a globok antagonizem med krščanstvom in sekularizmom je nepotreben, in še več, naravnost zmoten. Evropa (in z njo ves Zahod) sta namreč »sekularna ravno zato, ker sta krščanska« (Ferrari 2003), saj politični sekularizem temelji na ideji naravnega prava, ki je - čeprav izvira iz grškorimske kulture - lastna krščanstvu: tomistična teologija razvije idejo, da smo ljudje po naravi enaki in imamo zato enake pravice; pozneje ji razsvetljenstvo sicer spodmakne vir $\mathrm{v}$ transcendentalnem Bogu, a osnovna ideja ostane enaka. Iz nje neposredno izvira še en specifično evropski/ zahodnjaški koncept, ki je drugim civilizacijam pretežno tuj: univerzalne človekove pravice.

Idejni temelj ločitve politike in religije je torej po svojih izvorih grško-rimsko-krščanski (čeprav se ločitev v praksi zgodi proti volji in ob dejavnem nasprotovanju Cerkve). Pri tem velja poudariti, da to razsvetljensko načelo ni religiji sovražno. Ravno nasprotno, načelo ločitve države in religije šele omogoča sodoben koncept religijske svobode - ki seveda ni zgolj svoboda za največjo ali na nekem ozemlju »avtohtono « religijo, temveč mora biti svoboda za vse, tudi za manjšinske, nenavadne, nemara v očeh večine čudne religijske pa tudi nereligijske svetovne nazore. Hkrati pa velja ponoviti, da je sekularnost, ki se razvije iz razsvetljenske emancipacije družbenih in kulturnih področij izpod religijske dogme, glavni razlog za novoveško prevlado Zahoda in nastanek današnje globalne »zahodnistične« civilizacije, kot nam je to pokazal 
Aleš Debeljak (2012) v knjigi, ki že v naslovu metaforično zariše njeno večplastno naravo: Knjiga, križ, polmesec.

Sodobna Evropa je torej enkraten amalgam zelo dolge racionalne in sekularne tradicije, krščanstva ter islamskih vplivov. Njeno kompleksno kulturo je vsekakor vredno odločno braniti. Tudi pred islamisti, ki jo nedvomno ogrožajo, ko neposredno $\mathrm{z}$ vsemi sredstvi napadajo zahodnjaški multikulturalizem zaradi njegove domnevne grešnosti, $v$ imenu enega samega, edinega pravega načina življenja. A ob tem ne moremo spregledati, da enako počnejo fundamentalistični branilci čiste krščanske Evrope, ki z demagoškim razpihovanjem strahov pred domnevno islamsko grožnjo temeljne evropske vrednote ogrožajo neprimerno bolj kot muslimanski begunci. »Alarmizem o zatonu krščanstva spodjeda vrednote tolerance, enakosti, univerzalnih pravic, za obrambo katerih naj bi potrebovali krščansko Evropo. Erozija krščanstva ne bo nujno povzročila erozije teh vrednot. Goreče branjenje ,krščanske Evrope pred domnevnimi barbarskimi hordami pa jo lahko.» (Malik 2014)

Tako bo skorajšnji mujezinov klic z minareta ljubljanske džamije svojevrsten test zrelosti za slovensko družbo. Islamofobija ima namreč na Slovenskem že dolge korenine, ki časovno segajo občutno dlje od prelomnega 11. septembra 2001, kot nam v treh natančnih in poglobljenih analizah razkrije sociolog Srečo Dragoš (2003, 2004 in 2014). Pokaže tudi na specifiko slovenske islamofobije, ki jo poimenuje po Othellovem praporščaku »jagovski sindrom", s čimer označi "spletkarjenje in ščuvanje od zgoraj«: »Ko politične elite prižgejo nestrpnosti zeleno luč bodisi tako, da jo same sprožijo, ali pa tako, da jo tolerirajo - postane takšno tudi javno mnenje. Na Slovenskem se je nestrpnost vselej širila od zgoraj navzdol, in to $\mathrm{v} v$ vseh primerih, tako v zvezi $\mathrm{z}$ izbrisanimi, Romi, islamofobijo kot v zvezi z begunci.» (Dragoš 2017, s. p.) Največji del odgovornosti za družbeni odmev prihajajočega mujezinovega klica tako nosijo predvsem politiki, vidni predstavniki Rimskokatoliške cerkve in mediji. ${ }^{11}$

11 Da lahko predvsem politiki z odgovornim ravnanjem odločilno vplivajo na družbene razmere, zgovorno potrjuje osupljiv obrat, ki smo ga desetletje po žolčnih 


\section{ALEŠ ČRNIČ}

\section{LITERATURA}

Bartulović, Alenka. 2012. »'S Turkom star račun imamo, prav je, da ga poravnamo Vpadi osmanskih čet skozi diskurzivno optiko slovenskega zgodovinopisja in leposlovja ter njihova aplikativnost v enaindvajsetem stoletju. " V Imaginarni »Turek«, ur. Božidar Jezernik, 145-74. Ljubljana: Zavod RS za šolstvo.

Debeljak, Aleš. 2009a. »Evropa, islam in moderna paradigma.« Raziskave in razprave 2 (2): 51-72.

---. 20ogb. »Hvalnica hibridnosti: globalizacija in moderna zahodna paradigma.« Sodobnost 93 (10): 1235-46.

---. 2012. Knjiga, križ, polmesec. Ljubljana: Kulturpraktik.

Dragoš, Srečo. 2014. "Džamija - katalizator moralne panike.» Socialno delo 53 (2): 63-83.

---. 2003. "Islam in suicidalno podalpsko pleme.« Poročilo skupine za spremljanje nestrpnosti 02: 34-53.

---. 2004. »Islamofobija na Slovenskem. Poročilo skupine za spremljanje nestrpnosti 03: 10-27.

---. 2017. »Štirje jezdeci apokalipse (nestrpnosti).« Referat, predstavljen na simpoziju Knjiga, križ, polmesec - Islam in Zahod, 9. maj 2017, Ljubljana, Fakulteta za družbene vede.

Ferrari, Silvio. 2003. «What Distinguishes Europe from Other Civilizations.«Www. Chiesa, 3. oktober, 2003. http://chiesa.espresso.repubblica.it/articolo/6978\%26eng\%3 Dy.html.

Gingrich, Andre. 1998. „Frontier Myths of Orientalism: The Muslim World in Public and Popular Cultures of Central Europe." V Mediterranean Ethnological Summer School 2, ur. Bojan Baskar in Borut Brumen, 99-127. Ljubljana: Inštitut za multikulturne raziskave.

Jezernik, Božidar, ur. 2012. Imaginarni »Turek«. Ljubljana: Zavod RS za šolstvo.

Kumrular, Özlem. 2012. »Mediteranske konstrukcije ,Turka v šestnajstem stoletju: med samorefleksijo in antipropagando.« V Imaginarni »Turek«, ur. Božidar Jezernik, 41-66. Ljubljana: Zavod RS za šolstvo.

Malik, Kenan. 2014. »The Many Roots of Christian Europe.« Pandemonium: The Many Roots of Christian Europe, 2. marec, 2014. https://kenanmalik.com/2014/03/o2/ the-many-roots-of-christian-europe/.

razpravah, javnih demonstracijah in uspešnem zbiranju podpisov za referendum proti džamiji (ki ga je ustavilo šele Ustavno sodišče) doživeli februarja 2013, ko je ob odločnem županovanju Zorana Jankoviča mestni svet Mestne občine Ljubljana soglasno in tako rekoč brez javnih polemik dopolnil odlok, na podlagi katerega danes na robu središča slovenske prestolnice končno stoji džamija. 


\section{ŠTUDIJSKI VEČERI}

Mastnak, Tomaž. 1996. Kristjanstvo in muslimani. Ljubljana: Znanstveno in publicistično središče.

--- 2017. "Sovraštvo.« Mladina, posebna številka: Islam; zgodovina velike religije, 24. februar, 2017, 74-79.

Milton, Guy. 2016. "God and the Constitution." V God and the EU - Faith in European Project, ur. Jonathan Chaplin in Gary Wilton, 191-207. London: Routledge.

Moe, Christian. 2017. »Towards European Islams: Different Speeds, No GPS.« Referat, predstavljen na simpoziju Knjiga, križ, polmesec - Islam in Zahod, 9. maj 2017, Ljubljana, Fakulteta za družbene vede.

Muršič, Rajko. 2012. »O simbolnem drugačenju: ,Turek‘ kot grozeči drugi.« V Imaginarni »Turek«, ur. Božidar Jezernik, 27-40. Ljubljana: Zavod RS za šolstvo.

Said, Edward. 1996. Orientalizem: Zahodnjaški pogledi na Orient. Ljubljana: Studia humanitatis.

Shterin, Marat. 2017. »Islam and the ,West': Maybe What We ,Know' Isn't So?« Referat, predstavljen na simpoziju Knjiga, križ, polmesec - Islam in Zahod, 9. maj 2017, Ljubljana, Fakulteta za družbene vede.

Stark, Rodney. 2005. The Victory of Reason: How Christianity Led to Freedom, Capitalism, and Western Success. New York: Random House.

Šterbenc, Primož. 2011. Zahod in muslimanski svet: akcije in reakcije. Ljubljana: Založba FDV.

Weber, Max. (1905) 1988. Protestantska etika in duh kapitalizma. Ljubljana: Studia humanitatis.

https://doi.org/10.26493/2590-9754.14(28)129-146 